\title{
A Informática e o Desenvolvimento
}

\section{A INFORMAÇÃO E O GOVERNO}

O exercício do poder está extremamente vinculado com a posse da informação necessária para tomar decisões, que deve ser segura, oportuna, completa $e$ de qualidade. A capacidade e a habilidade de um govêrno para cumprir suas funções é o resultado direto da informação confiável e completa com que conta.

A informação na administração pública é recolhida, arquivada e posteriormente intercambiada entre todos os seus niveis para ser utilizada.

Deve-se, entretanto, estabelecer uma clara distinção entre a informação $e$ um Sistema de Informação para a Condução, governamental ou não.

A contabilidade do Estado é, em definitivo, um mecanismo de informaSão, e os registros do seu pessoal, outro mecanismo. Em geral, êstes mecanismos de informação cumprem, mais ou menos, uma finalidade determinada, mas não guardam nenhuma relação na compatibilidade entre si, e muitas vêzes fornecem a informação, porém tarde, e em forma não utilizável.

Ao contrário, um Sistema de Informação para a Condução integra todo os elementos de informação e os subsistemas de processamento de dados para prover, em tempo e modo opor- tuno, tôda a informaçăo necessária para planejar, organizar, dirigir e controlar as atividades do Estado.

Isto equivale a dizer que um Sistema de Informação para a Condução é a única maneira possivel de exercer o poder, é decerto governar em uma complexa sociedade atual, e isto é particularmente dramático quando por governar se entende não sòmente tomar decisões sôbre problemas imediatos senão decidir em função do futuro, como no caso dos problemas que surgem no processo de desenvolvimento.

O proceso de desenvolvimento causa problemas cuja complexidade requer que se deva recorrer à utilização das tecnologias mais avançadas para sua condução. Sem embargo, a continuação do problema tem características particulares e existem meios e vias de ação para solucioná-lo, tais como os Sistemas de Informação mencionados anteriormente.

\section{ADMINISTRAÇĀO PARA O DESENVOLVIMENTO}

A chave do êxito e do progresso de um país não se assenta sòmente em sua estrutura econômica nem em sua estrutura social, nem em sua estrutura

Sob a responsabilidade da Secretaria da Ciêncla e Tecnologia do Govêrno do Estado da Bahia. (Transcrito da Revista Aratu, de janeiro de 1970, ano III, n. ${ }^{\circ}$ 29.) 
política senão, fundamentalmente, em sua capacidade de condução administrativa.

Esta capacidade de condução que não está ligada à capacidade individual dos governantes e/ou funcionários, senão aos processos de informação e contrôle e aos mecanismos de decisão, é a razão que diferencia os países que avançam daqueles que estacionam ou que retrocedem.

Quando aos problemas de administração típicos de um país, região ou estado, se somam os derivados de um processo de desenvolvimento, a situação se torna ainda mais crítica, chegando-se, pela falta de um mecanismo de administração para o desenvolvimento, a resultados contrários aos buscados.

O notável neste problema é que apesar do exposto pode ver-se que os países têm encarado freqüentemente a institucionalização de autoridades de planejamento e ainda sistemas para o desenvolvimento, mas são excepcionais aquêles casos em que se tem ocupado de estabelecer um mecanismo de administração para o desenvolvimento eficaz.

Mas esta ausência de preocupação na condução do desenvolvimento é mais aparente do que real e resulta de que os governos não decidem criar uma nova superburocracia e considera que esta tarefa deveria ser realizada pelos canais comuns da administração. A chave do problema está em que os governos não têm reconhecido a necessidade de educar suas estruturas administrativas para fazê-las mais aptas, criando sistemas e processos de informação, ou se tem reconhecido, não têm encontrado os meios $e$ vias de ação para modificar o sistema administrativo.

\section{CENTRO DE INFORMATICA}

Para estabelecer um sistema eficaz de administração para o desenvolvimento, e para obter-se uma transformação profunda da burocracia (superior aos habituais esquemas de organização e métodos) se requer a implantação de um Centro de Informática que, entre outras funçöes, tenha a de promover e/ou supervisionar e/ou implantar Sistemas de Processamento de Dados Administrativos e Sistemas de Informação para a Condução Governamental.

Deve-se deixar claro que não é necessário que o Centro de Informática tenha participação ou interferência nos problemas do desenvolvimento, nem nos de planejamento, nem na administração, mas, se fôr necessário, que promova e eventualmente conduza 0 processo de criação de estruturas administrativas adequadas por meio da implantação de Sistemas de Informação para a Condução e Sistemas de Processamento de Dados Administrativos.

O Centro de Informática constitul, assim, o verdadeiro catalizador do desenvolvimento, favorecendo-o, sem participar no mesmo.

Para cumprir sua missão, o Centro de Informática deve cumprir, entre outras, as seguintes funções:

1. Criar os meios e modos de difusão para "sensibilizar" a Administração Pública e o Estado em geral, em relação ao uso e vantagens da Informática;

2. Estimular as iniciativas dos organismos da administração que vi- 
sem à automação do seu funcionamento;

3. Coordenar essas iniciativas em um contexto apropriado para homogeneizar as normas e procedimentos em participar em relação ao manuseio da informação;

4. Participar na formulação e pôr em prática a política estadual de automação da administração pública e de implementação de Sistemas de Informação para a Condução.

Muitos aspectos devem ser considerados para consolidar a existência de um organismo de informática e para assegurar-lhe uma vida útil, especialmente se a mesma há de ter relações estreitas com a área do Govêrno.

Nestes casos, como tôda vez que um corpo nôvo se inclui em um sistema existente, pode-se apresentar problemas de "rejeição", que devem ser previstos, analisados e neutralizados com antecipação.
Por outra parte, como todo organismo destinado a atuar em um setor avançado de conhecimento humano, deve possuir uma flexibilidade de condução e adaptação notável e a capacidade necessária, econômica e profissional, de captar técnicos do mais alto nivel intelectual.

Os parágrafos precedentes apresentam, aparentemente, situações opostas, pois, em geral, o setor público e em particular a participação do Estado, criam situações de instabilidade e de rigidez administrativa, e os niveis de retribuição são habitualmente pouco compatíveis. Existem, entretanto, modalidades que permitem somar os aspectos positivos da supervisão do Estado em problemas de interêsse público, à continuidade e flexibilidade que se requer no caso presente; e existem tecnologias que permitem inserir organismos desta natureza diminuindo ao mínimo a possibilidade de "rejeição". 
